\title{
CHANGES IN ENZYMATIC ACTIVITIES OF THE PINK BOLLWORM LARVAE TREATED WITH SOME BIOPESTICIDES
}

\author{
RASHED, M.M. ${ }^{1}$, EMANE M. MOUSTAFA ${ }^{2}$, NADIA M. ABD-ELMOAEN ${ }^{1}$ and \\ ALSHIMAA M.S.E. HASSAN ${ }^{2}$
}

1. Biochemistry Dept., Fac. Agric., Cairo Univ.

2. Central Agricultural Pesticides Laboratory, ARC, Dokki, Giza, Egypt.

(Manuscript received 24 July 2011)

\begin{abstract}
The present investigation aimed to clarify the changes in the enzymatic activities of the Pinkbollworm larvae treated with some biopesticides. Data showed that Abamectin( $1.8 \% \mathrm{EC})$ is the most effective than Spinosad (24\%SL ) on the third instar larvae of the pink bollworm (pectinophora gossypiella) (Saund) followed by Esfenvalerate (20\%EC) and Dipel 2x (6.4\%WP) (Bacillus thuringiensis) respectively. The LC50 of Abamectin, Spinosad, Esfenvalerate and Dipel $2 x$ caused increasing effect in protein concentration, reaching $28.8,25,48.9$ and $39.1 \%$ respectively in gut tissue of larvae after 6 hrs. of treatment. After 24 and 48 hrs. of treatment this content was decreased in Dipel $2 x$ and Abamectin by $33.1,33.5 \%$ and $39,26.3 \%$ respectively. But the treatment of Spinosad and Esfenvalerate increased the protein by 26.2, 13.2\% and $18,16.2 \%$ respectively. Great increase in activity of protease and glutathione-s-transferase enzymes was recorded in larvae after all intervals of treatment by the tested pesticides.

A high inhibitions in the activity of ATPase in larval tissues after all intervals of treatment except Abamectin and Esfenvalerate after $48 \mathrm{hrs}$. of treatment were occurred. A Significant increase in acid and alkaline phosphatase activities was detected in 6hrs. treatment of the four insecticides, but this response was changed after 24 and 48 hrs. of treatments .
\end{abstract}

Key words: Pinkbollworm, B.t., insecticide, Biochemical insecticides, enzymes activity.

\section{INTRODUCTION}

The pinkbollworm, Pectinophora gossypiella (Saund), is a serious and destructive insect pest of cotton bolls in Egypt. Many insecticides belongs to synthetic Pyrethroids, Organophosphorus and Carbamates are commonly used to control the pinkbollworm in fields. Such insecticides caused serious environmental and health problems (Hussein et. al., 2002). The biocontrol of insect pests using traditional microbial agents has been reported as a safe and economic method. One of the most promising biocontrol approach is Bacillus thuringiensis (B.t.) toxins as insecticides. The main mode of action of this crystalliferous bacterium was disrupting of the epithelial lining of the midgut-B.t. causes great physiological changes in the digestive system of infected insect (Cannan 1993). Another safer biocontrol agents are biochemical 
insecticides such as Abamectin and Spinosad. Abamectin acts as electro-physiological binding agents, affect chloride uptake, acetyl choline release and stimulate gammaamino butyric acid (GABA) (Cully et. al., 1999). Spinosad activates the nicotinic acetyl choline receptor and causes paralysis of insects (Waldron et al., 2000). Under insecticidal stress there are many adaptations in physiological mechanisms of treated insects (Nath et. al., 1997).

This work aims to study the toxicity of the four insecticide AAbamectin, Spinosad, Esfenvalerate (pyrethroid) and Dipel $2 x(B . t)$.$\} on the third instare larvae of$ Pinkbollworm under laboratory condition. Also to study the effect of $\left(\mathrm{LC}_{50}\right)$ of the tested insecticides on certain biochemical activities of the Pinkbollworm larvae such as:- Total protein, protease, ATPase, GST (glutathione-s-transferase), Acid and alkaline phosphatases.

\section{MATERIALS AND METHODS}

\section{1- Insect}

A laboratory strain of the pinkbollworm, pectinophora gossypiella (Saund) was reared on artificial diet as described by (Rashad and Ammer 1985), under constant conditions $\left(27 \pm 2{ }^{\circ} \mathrm{C}\right.$ and $70 \pm 5 \%$ R.H. $)$ for five years in centeral agriculture pesticides laboratory, with out any exposure to insecticides.

\section{2- Insecticides used}

1.2.1- The bacterial Formulation Dipel $2 \times(6.4 \% \mathrm{Wp}$ - Valent Biosciences) a commercial product based on Bacillus thuringiensis var kurstaki used at concentration of $1500,1125,750,562.5,375,281.25$ and 187.5 ppm .

1.2.2-Abamectin (Vertimec $1.8 \%$ EC - Syngenta) produced by an actinomycete bacterium, Streptomyces avermitilis, found in soil, used at 15.84, 11.52, 8.64, 5.76, 2.88, 1.44 and $0.72 \mathrm{ppm}$.

1.2.3- Spinosad (Spintor $24 \%$ SL - Dow Agrosciences) made up of two complex organic compounds, spinosyn A (right) and spinosyn D. These compounds are produced by certain microbes, used at 144, 108, 72, 54, 36, 18 and 9 ppm.

1.2.4- Esfenvalerate ( $20 \%$ EC Sumi -gold KZ- Kafr Elzayate) pyrethroid insecticide used at 150, 120, 90, 60, 45, 30 and 15 ppm.

Each concentration was mixed with artificial diet in twenty glass tubes $(0.1 \mathrm{ml} / 5 \mathrm{gm}$ wt.) then $3^{\text {rd }}$ instar larvae were transferred individually to treated and untreated tubes (Five replicates of each treatment). Mortality was counted after 6, 24 and 48 hours of treatment. All data were analyzed using SAS probit (1997). 


\section{3- Biochemical assays}

The untreated and treated $3^{\text {rd }}$ instar larvae were dissected and the gut tissues were isolated from larvae. Hundred milligrams of gut tissues were homogenized in 3 $\mathrm{ml}$ of sodium phosphate buffer $(\mathrm{pH} 7)$ using a teflon homogenizer surrounded by a jacket of crushed ice and centrifuged for $30 \mathrm{~min}$ at $10000 \mathrm{rpm} / \mathrm{min}$. Then supernatant was transferred to new tubes and was preserved at $-20^{\circ} \mathrm{C}$. The total protein content was measured based on Biuret's method (Henry 1964). In this method proteins made a complex of violet blue color with an alkaline copper solution, which absorption value at $545 \mathrm{~nm}$ has a direct relation to the amount of protein .

\subsection{1- Adenosine triphosphatase assay}

The activity of the enzyme was assayed according to the method described by (Shiosaka et al., 1971). In this method, the protein was precipitated with trichloroaceticacid.

The protein free filtrate was treated with acid molybdate solution and the phosphoric acid formed was reduced by the addition of 1-amino-2-naphthol-4sulphoric acid (ANSA) reagent to produce blue color. The intensity of the color was proportional to the amount of phosphorous present.

\subsection{2- Glutathione-s-transferase assay}

CDNB (1-chloro-2, 4- dinitrobenzene) substrate was used to measure the enzyme activity. The conjugated glutathione was measured at $340 \mathrm{~nm}$ for $2 \mathrm{~min}$ and activity was calculated with an extinction coefficient of $9.6 \mathrm{mM} / \mathrm{cm}$ for CDNB (Kristensen, 2005).

\subsection{3- Phosphatase enzymes assay}

Disodiumphenylphosphate (Substrate) was hydrolyzed by the enzyme and the released phenol was reacted with 4- amino anti pyrine by which brown color was appeared by addition of potassium ferricyanide, this color was measured at $510 \mathrm{~nm}$ (Powell and Smith 1954).

\subsection{4- Protease assay}

Azocasein was used as substrate in carbonate buffer $\left(\mathrm{NaHCO}_{3}-\mathrm{NaCO}_{3} \mathrm{pH}\right.$ 11) to measure the activity of protease enzyme at $450 \mathrm{~nm}$ after addition of $1 \mathrm{M} \mathrm{NaOH}$ was described by (Brik et al., 1962) with some modification by (Wang et al., 2007).

\section{RESULTS AND DISCUSSION}

\section{Effect of tested pesticides on $3^{\text {rd }}$ larval instare of the Pinkbollworm}

Data in table (1) showed that Abamectin was the most potent insecticide $\left[\mathrm{LC}_{50}=7.21,3.67\right.$ and $1.82 \mathrm{ppm}$ with toxicity index (T.I.) $100 \%$ ] Followed by 
Spinosad ( $63.33,38.25$ and 16.14 ppm with $11.39,10.00$ and $11.28 \%$ T.I. ) and Esfenvalerate ( $79.80,41.00$ and 18.55 ppm with $9.04,8.95$ and $9.81 \%$ T.I. ) against $3^{\text {rd }}$ instar larvae after 6,24 and 48 hours of treatment, respectively. $B$. thuringensis var kurstaki (Dipel 2x) had the lowest effect (896.42, 641.18 and 318.74 ppm and $0.08,0.57$ and $0.57 \%$ T.I.) on these larvae at the same intervals, respectively. These results agree with those of Hussein et al., (2002) who mentioned that Vertimec $1.8 \% \mathrm{EC}\left(\mathrm{LC}_{50}=0.02 \mathrm{ppm}\right)$ was more effective on $p$. gossypiella larvae than neemazal-T5\%SC ( $\left.\mathrm{LC}_{50}=50 \mathrm{ppm}\right)$. Radwan (2002) reported that toxicity of Spinosad 24\% SL was high than Dipel-2x 6.4\% WP and Agerin 6.5\%WP $\left(\mathrm{LC}_{50}=6.47\right.$, 8.58 and $43.99 \mathrm{ppm}$ respectively) to the last instar larvae of spiny bollworm.

\section{Total protein content and protease activity in gut tissue of $3^{\text {rd }}$ instare larvae of the Pinkbollworm}

Data in table (2) showed that the treatment of $p$. gossypiella with $\mathrm{LC}_{50}$ of Esfenvalerate, Dipel 2x, Abamectin and Spinosad pesticides caused the increasing values in gut protein, reaching $48.9,39.1,28.8$ and $25 \%$,respectively after 6 hours. But after 24 and 48 hours of treatment the increasing effect was recorded in Spinosad at 26.2 and $13.2 \%$ and Esfenvalerate of 18 and $16.2 \%$. On the other hand Dipel 2x ( B.t.) of 33.1 and $33.5 \%$ and Abamectin of 39 and $26.3 \%$ decreased the gut protein. These results agree with Nath et al., 1997, who mentioned that protein depletion in tissues may constitute a physiological mechanism and might play a role in compensatory mechanisms under insecticidal stress to provide intermediates to the Krebs cycle by retaining free amino acid content in insect tissues.

Protease activity was stimulated with all tested insecticides after 6, 24 and 48 hrs. of treatments, especially Esfenvalerate which caused the highest stimulation $454.5,482.7$ and $178.4 \%$, respectively. The higher activity of protease after $48 \mathrm{hrs}$. was pronounced with B.t. treatment (346.4\%), this due to the mode of action of the (B.t.) that produces crystals that contain insecticidal crystal proteins (ICPs). ICPs, or Cry proteins, are in the form of protoxins in the crystal. ICPs are solubilized and processed to toxic peptides by gut proteases in susceptible insects. Because proteases are important to toxicity, research into interactions of prteases with Bt proteins may lead to improved toxin efficacy. Insect gut proteases are involved in crystal dissolution and protoxin activation and contribute to toxin specificity.

Insect proteases can further degrade activated ICPs; they may also be involved in receptor-toxin interactions and post-binding events. (Oppert, 1999). 


\section{Activity of ATPase and GST (glutathione-s-transferase) in gut tissue of 3rd instare larvae of the Pinkbollworm}

Data in table (3) revealed that all tested pesticides, in general, had inhibiting effects on the activity of ATPase of p. gossypiella gut after 6, 24, 48 hrs., except the treatments of Esfenvalerate and Spinosad after $48 \mathrm{hrs}$. which produced stimulating effect on the activity of enzyme (43.9 and $21.5 \%$ ) respectively. The insecticidal treatments disturb absorption of metabolites and nutrients (Zibae et al., 2008). GST activity was highly increased with Esfenvalerate (98.2, 81.2 and $111.2 \%)$, B.t. Dipel 2x (88.2, 19.4, 82.9\%), Spinosad (23.8, 63.5 and 21.7\%) and Abamectin (11.3, 24.7 and $182.9 \%$ ) after 6.24 and 48 hrs. of treatment. Sivori et al., 1997 mentioned that pyrethroid insecticides showed a significant increase in GST activity in terms of specific enzyme activity.

\section{Activity of acid and alkaline phosphatase in gut tissue of 3 rd larval Instare of the Pinkbollworm}

Data in table (4) showed the significant stimulation in acid phosphatase enzyme with all treatment after 6 hrs. , and after 24 hrs. with Dipel 2x and Abamectin and after 48 hrs. with Abamectin only. The highly stimulation in enzyme activity was recorded in Esfenvalerate treatment after 6 hrs. (89\%). Also a significant decreased value (38\%) was recorded after $48 \mathrm{hrs}$. of the same insecticide.

The significant stimulation in alkaline phosphatase activity was occurred by Abamectin (74.1\%) and Spinosad (64.3\%) than the other two pesticides at 6hrs. treatments, and Esfenvalerate (86\%) after 24 hrs. and Dipel 2x (83.6 \%) and Spinosad (54.6\%) after 48 hrs. treatments. There is a slight inhibition in enzyme activity after 24 hrs. treatments of Dipel $2 \times(11.4 \%)$ and Spinosad (8.3\%) and after $48 \mathrm{hrs}$. of treatments with Esfenvalerate (24\%) and Abamectin (3.8\%) . Hussein et. al., (2002) recorded the high reduction in acid and alkaline phosphatase in treated $P$. gossypiella with Abamectin than the control ones. 
Table 1. Effect of tested pesticides on $3^{\text {rd }}$ larval instare of $P$. gossypiella (Saund)

\begin{tabular}{|c|c|c|c|c|c|}
\hline \multicolumn{2}{|c|}{$\begin{array}{l}\text { Treatment } \\
\text { intervals }\end{array}$} & Abamectin & Spinosad & Esfenvalerate & B.t. \\
\hline \multirow{4}{*}{ 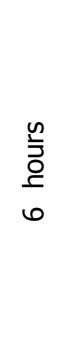 } & LC $C_{50}(\mathrm{ppm})$ & 7.21 & 63.33 & 79.80 & 896.42 \\
\hline & Slope & 1.60 & 1.71 & 1.48 & 1.26 \\
\hline & 土S.D. & \pm 0.465 & \pm 0.214 & \pm 0.333 & \pm 0.558 \\
\hline & $\begin{array}{c}\text { Toxicity index } \\
\text { (\%) }\end{array}$ & 100 & 11.39 & 9.04 & 0.80 \\
\hline \multirow{4}{*}{ 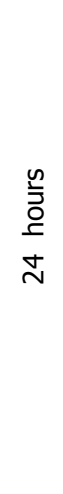 } & $\mathrm{LC}_{50}(\mathrm{ppm})$ & 3.67 & 38.25 & 41.00 & 641.18 \\
\hline & Slope & 1.39 & 2.26 & 1.52 & 1.22 \\
\hline & 土S.D. & \pm 0.348 & \pm 0.119 & \pm 0.228 & \pm 0.356 \\
\hline & $\begin{array}{c}\text { Toxicity index } \\
(\%)\end{array}$ & 100 & 10.00 & 8.95 & 0.57 \\
\hline \multirow{4}{*}{ 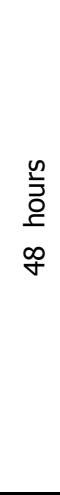 } & $\mathrm{LC}_{50}$ (ppm) & 1.82 & 16.14 & 18.55 & 318.74 \\
\hline & Slope & 1.55 & 1.50 & 1.36 & 1.43 \\
\hline & \pm S.D. & \pm 0.174 & \pm 0.283 & \pm 0.347 & \pm 0.168 \\
\hline & $\begin{array}{c}\text { Toxicity } \\
\text { index(\%) }\end{array}$ & 100 & 11.28 & 9.81 & 0.57 \\
\hline
\end{tabular}

Toxicity index $(\%)=\underline{L_{5}} \underline{{ }_{0}}$ of the most effective insecticide $\times 100$

$$
\mathrm{LC}_{50} \text { of the other insecticide }
$$


Table 2. Total protein content and protease activity in control and treated $3^{\text {rd }}$ instare larvae in gut tissue of p. gossypiella (Saund)

\begin{tabular}{|c|c|c|c|c|c|c|c|c|c|c|c|c|}
\hline \multirow{2}{*}{$\begin{array}{c}\text { Treatment } \\
\text { Intervals }\end{array}$} & \multicolumn{6}{|c|}{$\begin{array}{c}\text { Conc. of protein } \\
\text { Mean } \pm \text { S.D. } \\
\text { mg / } 100 \text { mg gut tissue }\end{array}$} & \multicolumn{6}{|c|}{$\begin{array}{c}\text { Activity of protease } \\
\text { Mean } \pm \text { S.D. } \\
\text { O.D unit } \times 10^{3} / \mathrm{min} / 100 \mathrm{mg} \text { gut tissue }\end{array}$} \\
\hline & 6 hrs. & $\begin{array}{c}\text { Change } \\
\%\end{array}$ & 24 hrs. & $\begin{array}{c}\text { Change } \\
\%\end{array}$ & 48 hrs. & $\begin{array}{c}\text { Change } \\
\%\end{array}$ & 6 hrs. & $\begin{array}{c}\text { Change } \\
\%\end{array}$ & 24 hrs. & $\begin{array}{c}\text { Change } \\
\%\end{array}$ & 48 hrs. & $\begin{array}{c}\text { Change } \\
\%\end{array}$ \\
\hline Control & $\begin{array}{c}1.84 \mathrm{C} \\
\pm 0.735\end{array}$ & 0.0 & $\begin{array}{c}1.72 \mathrm{a} \\
\pm 0.011\end{array}$ & 0.0 & $\begin{array}{r}1.67 \mathrm{a} \\
\pm 0.328\end{array}$ & 0.0 & $\begin{array}{l}277.14 \mathrm{C} \\
\pm 0.274\end{array}$ & 0.0 & $\begin{array}{c}262.96 \mathrm{C} \\
\pm 1.602\end{array}$ & 0.0 & $\begin{array}{l}258.22 \mathrm{C} \\
\pm 0.628\end{array}$ & 0.0 \\
\hline Dipel 2x & $\begin{array}{c}2.56 \mathrm{a} \\
\pm 0.567\end{array}$ & +39.1 & $\begin{array}{c}1.15 \mathrm{~b} \\
\pm 0.304\end{array}$ & -33.1 & $\begin{array}{c}1.11 \mathrm{~b} \\
\pm 1.271\end{array}$ & -33.5 & $\begin{array}{l}420.26 \text { a } \\
\pm 1.72\end{array}$ & +51.6 & $\begin{array}{c}152.82 \mathrm{a} \\
\pm 248.8\end{array}$ & +338.4 & $\begin{array}{l}693.40 \mathrm{~b} \\
\pm 0.403\end{array}$ & +168.5 \\
\hline Abamectin & $\begin{array}{c}2.37 \mathrm{~b} \\
\pm 0.394\end{array}$ & +28.8 & $\begin{array}{c}1.05 \mathrm{~b} \\
\pm 0.105\end{array}$ & -39 & $\begin{array}{c}1.23 \mathrm{~b} \\
\pm 0.378\end{array}$ & -26.3 & $\begin{array}{l}438.65 \mathrm{a} \\
\pm 9.88\end{array}$ & +58.2 & $\begin{array}{l}604.62 \mathrm{~b} \\
0.625 \pm\end{array}$ & +129.9 & $\begin{array}{l}927.24 \mathrm{a} \\
\pm 0.417\end{array}$ & +259 \\
\hline Spinosad & $\begin{array}{c}2.30 \mathrm{~b} \\
\pm 0.666\end{array}$ & +25 & $\begin{array}{c}2.17 \mathrm{a} \\
\pm 1.006\end{array}$ & +26.2 & $\begin{array}{c}1.89 \mathrm{a} \\
\pm 1.061\end{array}$ & +13.2 & $\begin{array}{l}364.80 \mathrm{~b} \\
\pm 0.973\end{array}$ & +31.6 & $\begin{array}{l}625.28 \mathrm{~b} \\
\pm 0.625\end{array}$ & +137.7 & $\begin{array}{l}864.77 \mathrm{a} \\
\pm 1.078\end{array}$ & +234.8 \\
\hline Esfenvalerate & $\begin{array}{c}2.74 \mathrm{a} \\
\pm 0.183\end{array}$ & +48.9 & $\begin{array}{c}2.03 \mathrm{a} \\
\pm 1.158\end{array}$ & +18 & $\begin{array}{c}1.94 \mathrm{a} \\
\pm 1.000\end{array}$ & +16.2 & $\begin{array}{l}336.63 \mathrm{~b} \\
\pm 1.603\end{array}$ & +21.4 & $\begin{array}{l}642.34 \mathrm{~b} \\
\pm 0.689\end{array}$ & +144.2 & $\begin{array}{l}818.97 \mathrm{a} \\
\pm 0.400\end{array}$ & +217.15 \\
\hline
\end{tabular}

Change $\%=$ Treatment - Control $\times 100$

Control

Means followed by the same letter at the same column are not significantly different. 
Table 3. Activity of ATPase and GST (glutathione-s-transferase) in gut tissue of control and treated 3rd instare larvae of p. gossypiella (Saund)

\begin{tabular}{|c|c|c|c|c|c|c|c|c|c|c|c|c|}
\hline Treatment & \multicolumn{6}{|c|}{ ATPase ( $\mu \mathrm{mol} / \mathrm{mg}$ protein / $\mathrm{min}$ ) } & \multicolumn{6}{|c|}{ GST ( $\mu$ mol / mg protein / min ) } \\
\hline Intervals & 6 hrs. & $\begin{array}{c}\text { Change } \\
\%\end{array}$ & 24 hrs. & $\begin{array}{c}\text { Change } \\
\%\end{array}$ & 48 hrs. & $\begin{array}{c}\text { Change } \\
\%\end{array}$ & 6 hrs. & $\begin{array}{c}\text { Change } \\
\%\end{array}$ & 24 hrs. & $\begin{array}{c}\text { Change } \\
\%\end{array}$ & 48 hrs. & $\begin{array}{c}\text { Change } \\
\%\end{array}$ \\
\hline Control & $\begin{array}{l}48.35^{\mathrm{a}} \\
\pm 3.17\end{array}$ & 0.0 & $\begin{array}{l}42.73 \mathrm{a} \\
\pm 3.22\end{array}$ & 0.0 & $\begin{array}{l}37.60 \mathrm{a} \\
\pm 2.61\end{array}$ & 0.0 & $\begin{array}{c}99.76 \mathrm{C} \\
\pm 10.25\end{array}$ & 0.0 & $\begin{aligned} \text { C } & 90.28 \\
& \pm 5.42\end{aligned}$ & 0.0 & $\begin{array}{c}83.17 \mathrm{~d} \\
\pm 6.50\end{array}$ & 0.0 \\
\hline Dipel 2x & $\begin{array}{l}35.51 \mathrm{~b} \\
\pm 2.21\end{array}$ & -26.6 & $\begin{array}{l}29.92 \mathrm{~b} \\
\pm 2.04\end{array}$ & -30 & $\begin{array}{l}29.33 \mathrm{~b} \\
\pm 1.82\end{array}$ & -22.0 & $\begin{array}{l}187.79 \mathrm{a} \\
\pm 15.80\end{array}$ & +88.2 & $\begin{array}{l}107.81 \mathrm{~b} \\
\pm 4.15\end{array}$ & +19.4 & $\begin{array}{l}152.08 \mathrm{~b} \\
\pm 5.11\end{array}$ & +82.9 \\
\hline Abamectin & $\begin{array}{l}26.19 \mathrm{C} \\
\pm 2.65 \\
\end{array}$ & -45.8 & $\begin{array}{r}19.24 \mathrm{C} \\
\pm 3.79 \\
\end{array}$ & -55 & $\begin{array}{r}45.67 \mathrm{a} \\
\pm 1.64 \\
\end{array}$ & +17.7 & $\begin{array}{l}111.05 \mathrm{~b} \\
\pm 9.41\end{array}$ & +11.3 & $\begin{array}{l}112.57 \mathrm{~b} \\
\pm 7.24\end{array}$ & +24.7 & $\begin{array}{r}235.26 \mathrm{a} \\
\pm 8.36 \\
\end{array}$ & +182.9 \\
\hline Spinosad & $\begin{array}{l}29.60 \mathrm{C} \\
\pm 2.73 \\
\end{array}$ & -38.8 & $\begin{array}{l}22.13 \mathrm{C} \\
\pm 2.96 \\
\end{array}$ & -48.2 & $\begin{array}{l}21.81 \mathrm{C} \\
\pm 3.11\end{array}$ & -42.0 & $\begin{array}{r}123.50 \mathrm{~b} \\
\pm 11.48 \\
\end{array}$ & +23.8 & $\begin{array}{r}147.62 \mathrm{a} \\
6.18 \pm\end{array}$ & +63.5 & $\begin{array}{l}101.22 \mathrm{C} \\
\pm 4.71 \\
\end{array}$ & +21.7 \\
\hline Esfenvalerate & $\begin{array}{l}20.83 \mathrm{~d} \\
\pm 3.12\end{array}$ & -56.9 & $\begin{array}{l}31.73 \mathrm{~b} \\
\pm 1.64\end{array}$ & -25.7 & $\begin{array}{l}42.21 \mathrm{a} \\
\pm 1.17\end{array}$ & +12.3 & $\begin{array}{c}197.73 \mathrm{a} \\
\pm 13.97\end{array}$ & +98.2 & $\begin{array}{l}163.55 \mathrm{a} \\
\pm 10.88\end{array}$ & +81.2 & $\begin{array}{c}175.68 \mathrm{~b} \\
\pm 12.73\end{array}$ & +111.2 \\
\hline
\end{tabular}

Change\% $=\underline{\text { Treatment }- \text { Control } \times 100}$ Control

Means followed by the same letter at the same column are not significantly different. 
Table 4. Activity of acid and alkaline phosphatase in gut tissue of control and treated 3 rd larval Instare of p. Gossypiella (Saund)

\begin{tabular}{|c|c|c|c|c|c|c|c|c|c|c|c|c|}
\hline \multirow{3}{*}{$\begin{array}{l}\text { Treatment } \\
\text { Intervals }\end{array}$} & \multicolumn{12}{|c|}{ Activity of acid and alkaline phosphatase ( $\mu \mathrm{mol} / \mathrm{mg}$ protein / $\mathrm{min}$ ) } \\
\hline & \multicolumn{6}{|c|}{ Acid } & \multicolumn{6}{|c|}{ Alkaline } \\
\hline & 6 hrs. & $\begin{array}{c}\text { Change } \\
\%\end{array}$ & 24 hrs. & $\begin{array}{c}\text { Change } \\
\%\end{array}$ & 48 hrs. & $\begin{array}{c}\text { Change } \\
\%\end{array}$ & 6 hrs. & $\begin{array}{c}\text { Change } \\
\%\end{array}$ & 24 hrs. & Change\% & 48 hrs. & $\begin{array}{c}\text { Change } \\
\%\end{array}$ \\
\hline Control & $\begin{array}{c}1.01 \mathrm{~d} \\
0.082 \pm\end{array}$ & 0.0 & $\begin{array}{c}1.35 \mathrm{C} \\
0.056 \pm\end{array}$ & 0.0 & $\begin{array}{c}1.42 \mathrm{a} \\
0.016 \pm\end{array}$ & 0.0 & $\begin{array}{c}15.34 \mathrm{C} \\
0.341 \pm\end{array}$ & 0.0 & $\begin{array}{c}14.23 \mathrm{~b} \\
0.215 \pm\end{array}$ & 0.0 & $\begin{array}{c}14.19 \mathrm{C} \\
0.181 \pm\end{array}$ & 0.0 \\
\hline Dipel 2x & $\begin{array}{c}1.24 \mathrm{C} \\
0.036 \pm\end{array}$ & +22.8 & $\begin{array}{c}1.98 \mathrm{a} \\
0.011 \pm\end{array}$ & $46.7+$ & $\begin{array}{c}1.28 \mathrm{~b} \\
0.042 \pm\end{array}$ & $9.9 \quad-$ & $\begin{array}{c}20.64 \mathrm{~b} \\
0.522 \pm\end{array}$ & +34.6 & $\begin{array}{c}12.61 \mathrm{~b} \\
0.625 \pm\end{array}$ & -11.4 & $\begin{array}{c}26.05 \text { a } \\
0.317 \pm\end{array}$ & +83.6 \\
\hline Abamectin & $\begin{array}{c}1.46 \mathrm{~b} \\
0.027 \pm\end{array}$ & $44.6+$ & $\begin{array}{c}1.78 \mathrm{~b} \\
0.046 \pm\end{array}$ & +31.9 & $\begin{array}{c}1.59 \mathrm{a} \\
0.026 \pm\end{array}$ & +12 & $\begin{array}{c}26.70 \mathrm{a} \\
0.417 \pm\end{array}$ & +74.1 & $\begin{array}{c}15.44 b \\
0.818 \pm\end{array}$ & +8.5 & $\begin{array}{c}13.65 \mathrm{C} \\
0.255 \pm\end{array}$ & -3.8 \\
\hline Spinosad & $\begin{array}{c}1.59 \mathrm{~b} \\
0.018 \pm\end{array}$ & $57.4+$ & $\begin{array}{c}1.15 \mathrm{C} \\
0.029 \pm\end{array}$ & $14.8^{-}$ & $\begin{array}{c}1.31 \mathrm{~b} \\
0.033 \pm\end{array}$ & -7.8 & $\begin{array}{c}25.20 \mathrm{a} \\
0.354 \pm\end{array}$ & +64.3 & $\begin{array}{c}13.05 \mathrm{~b} \\
0.436 \pm\end{array}$ & -8.3 & $\begin{array}{c}21.93 \mathrm{~b} \\
0.542 \pm\end{array}$ & +54.6 \\
\hline Esfenvalerate & $\begin{array}{c}1.91 \mathrm{a} \\
0.044 \pm\end{array}$ & $89.1+$ & $\begin{array}{c}0.95 \mathrm{~d} \\
\pm 0.051\end{array}$ & -29.6 & $\begin{array}{c}0.88 \mathrm{C} \\
0.023 \pm\end{array}$ & -38 & $\begin{array}{c}20.72 \mathrm{~b} \\
0.762 \pm\end{array}$ & +35.1 & $\begin{array}{c}26.47 \mathrm{a} \\
0.717 \pm\end{array}$ & +86 & $\begin{array}{c}10.79 \mathrm{~d} \\
0.349 \pm\end{array}$ & -24 \\
\hline
\end{tabular}

Change $\%=\underline{\text { Treatment }- \text { Control }} \times 100$ Control

Means followed by the same letter at the same column are not significantly different. 


\section{REFERENCES}

1. Brik, Y., I. Harpaz, I. Ishaaya and A. Bondi. 1962. Studies on the proteolytic activity of the beetles Tenebrio and tribolium. J. Insect Physiol., 24:699-705.

2. Cannon, R.J.C. 1993. Prospects and progress for Bacillus thuringiensis based pesticides. Pestic. Sci., 37:331-335.

3. Cully, D.F., D.K. Vassilatis, K.K. Liu, P.S. Paress, L.H. Vander-ploeg, J.M. Schaeffer and J.P. Arena.1999. Cloning of an Avermectin sensitive glutamate chloride channel from caenorhadditis elegans. Nature, 371:701-711.

4. Henery, R.J. 1964. Clinical chemistry (Harper and Row publishers.) New york p:181.

5. Hussein, Nagwa M., A.I. Gadallah, S.M. Tawfik and Mona A.A. Hewady. 2002. The changes in the enzymatic activities in the larvae of bollworm induced by Vertimec and

6. Neemazal in their artifical diet. The First Conf. of the central. Agric. Pest. Lab. 3-5 Sep, 2:589-600.

7. Kristensen, M. 2005. Glutathione-S-Transferase and insecticide resistance in laboratory strain and field populations of Musca domestica. J. Econ. Entomol.,

8. 98(4):1341-1348.

9. Nath, B.S., A. Suresh, B. Mahendra-Varma and P.P. Kumar. 1997. Changes in protein metabolism in hemolymph and fat body of the silkworm, Bombyx mori (L.) in response to organophosphorus insecticides toxicicty. Ecotoxicol. Environ. Safety 36:119-137.

10. Oppert, B. 1999. Protease interactions with Bacillus thuringiensis insecticidal toxins. Arch. Insect Biochem. physiol. 42(1):1-12.

11. Powell, M.E.A. and M.J.H. Smith. 1954. The determination of serum acid and alkaline phosphatases activity with 4-aminoantipyrine. J. Clin. Pathol., 7:245248.

12. Radwan, Eman M.M. 2002. Response of spiny bollworm, Earias insulana (Boisd.) larvae to certain biopesticides. The first conf. of the central Agric. pest. Lab. 3-5 Sep, 2:563-575.

13. Rashad, Amira M. and E.D. Ammar. 1985. Mass rearing of spiny bollworm, Earias insulana (Boisd.) on semi-artificial diet. Bull. Soc. Ent. Egypt, 65:239-244.

14. SAS Institute 1997. SAS/STAT user's guide for personal computers SAS Institute, Cary. N. C. 
15. Shiosaka, T., H. Okuda and S. Fujii. 1971. Mechanism of the phosphorylation of thymidine by the culture filtrate of clostridium perfringens and rat liver extract. Biochem. and Biophesis Acta., 246:171-183.

16. Sivori, J., N. Casabe, E.N. Zerba and E.J. Wood. 1997. Induction of glutathione-stranseferase activity in Triatom infestans. Mem. Inst. oswaldo Gruz, Riode Janeiro, 92(6):797-802.

17. Waldron, C., M. Krishnamarthy, K. Crawford, D.J. Merlo, P. Treadway, M.C. Broughton and R.H. Balt. 2000. A cluster of genes for the biosynthesis of spinosyns, novel macrolide insect control agents produced by Saccharopolyspora spinosa. (Ed. Karagouni, A. and koraki, D.) Antonie Van Leeuwenhoek, 78(3/4):385-390.

18. Wang, P., J.Z. Zhoo, A.R. Simon, W. Kain, A.F. Janmaat, A.M. Shelton, J. Ferre and J. Myers. 2007. Mechanism of resistance to Bacillus thuringiensis toxin Cry1AC in a green house population of the cabbage looper, Trichoplusia ni. Appl. Environ. Microbiol., 73(4):1199-1207.

19. Zibae, A., J.J. Sendi, K. Etebari, F. Alinia and M.Ghadamyri. 2008. The effect of diazinon on some biochemical characteristics of Chilo Suppressalis walker (Lepidoptera: pyralidae), rice striped stem borer Mum. Ent. Z00I., 3(1):255-265. 


\section{التغيرات فى الانشطة الانزيمية ليرقات ديدان اللوز القزنفلية

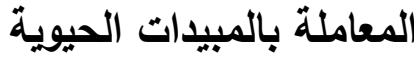

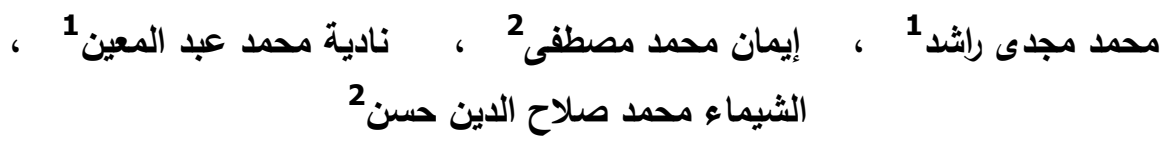

$$
\text { 2- } 1 \text { - كلية الزراعة- جامعة القاهن المركزى للمبيدات - مركز البحوث الزراعية - الدقى - الجيزة - مصر }
$$

إستهدفت الدراسات البيوكيميائية إلى إيضـاح التغيرات فى الانشطة الإنزيمية ليرقات ديدان

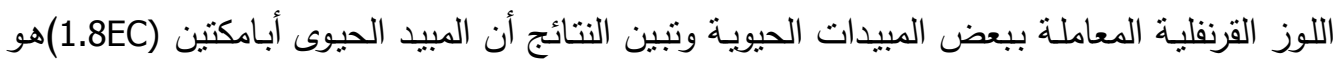

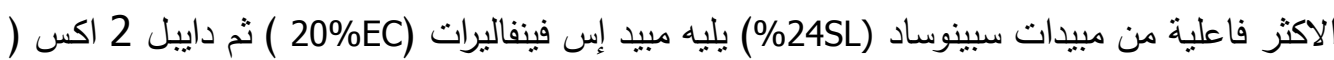
.(6.4 \%WP

وقد تسبيت المعاملة بالتركيز النصفى المميت لل( أبامكتين سبيينوساد - إس فينفاليرات - ـاييل 2 اكس ) فى زيادة تركيز بروتين انسجة معى اليرقات بعد ستة ساعات من المعاملة بنسب (28.8،

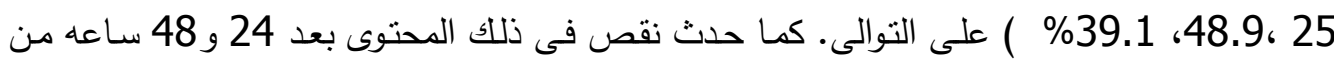

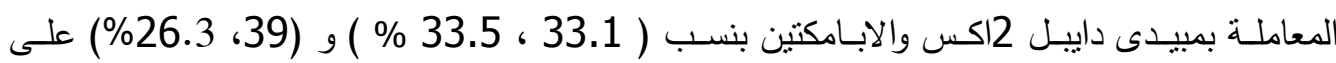

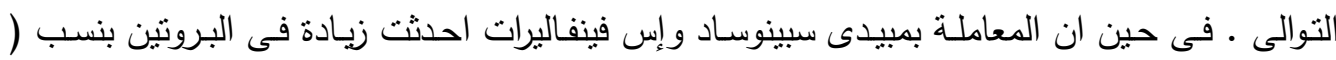

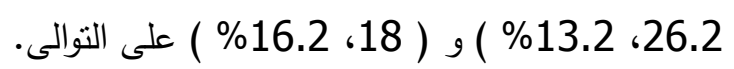

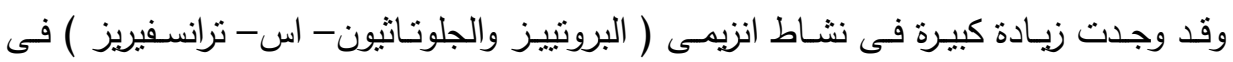

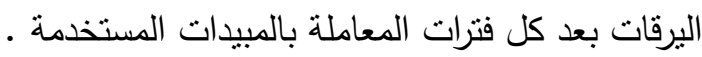
كما حدث تثبيط مرتفع فى نشاط انزيم (ادينوسين تراى فوسفاتيز) فى انسجة اليرقات بعد كل فترات المعاملة ما عدا ( الابامكتين و إس فينفاليرات ) بعد 48 ساعة من المعاملة. كما سجلت زيادة معنوية فى نشاط انزيمى الفوسفاتيز الحامضى والقاعدى بعد ستة ساعات من الحن المعاملة بالمبيدات الاربع، لكن هذه الاستجابة تغيرت بعد 24، 48 ساعة من المعاملة. 